\title{
Obtaining Language in Children 2.5 Aged Years Old Phonology and Syntax Study
}

\author{
Dernius Hura $^{1(*)}$, Agustina $^{1}$ \\ ${ }^{1}$ Faculty of Language and Art, Universitas Negeri Padang, Padang, Indonesia, \\ "Corresponding author. Email: dernihura@student.unp.ac.id
}

\begin{abstract}
The purpose of this research is to learn how to study the language of 2.5-year-old children based on phonology and syntax that they produce. This research is a case study of children. The research data was obtained by opening a direct conversation and the conversation was talking to parents and siblings. To retrieve the data, the researcher gives freedom of stimulus to the children who are the subject of research so that they can talk and talk about the syntax they produce. This research turned out to show the results that, acquisition of phonology and syntax that has been recorded from children aged 2.5 years to produce words that have no meaning, the words that appear the most are pronouns / pronouns. After being given a stimulus to the child to speak, can produce words that have meaning and also produce several types of words including, nouns that are said up to two, three in one utterance and some are cut off.
\end{abstract}

\section{Keywords: Acquisition of language, Phonology, Syntax}

\section{INTRODUCTION}

We often encounter cases in children when uttering a word, whether the word that is said has meaning or not, even difficult to understand. to make it easier to understand it can be seen from the movements of his hands, eyes, and mouth movements when he conveys messages to those around him. Such cases are very unique to a child, and this uniqueness is possessed by humans.

Some linguistics experts claim that actually language cannot be imparted to other creatures besides humans, because it is humans who are only able to speak. Every person is given a language from when he was in the womb until he was born. Obtaining language is a very long process that children do not know a language until they are fluent (Fatmawati, 2015). Whereas according to (Ulfa, 2017) language acquisition or acquisition is a process that takes place in the brain of a child when he gets his first language from mother tongue. (Suddhono, Sumarlam, \& Pandudinata, 2018) Language learning is related to the processes that occur when a child learns a second language after he has obtained the first language or language. Thus, language acquisition is related to the first language or mother tongue and second language learning is related to foreign languages or second languages (Chaer, 2015: 167). The explanation above relates to the current habits of the community which assume that language acquisition and learning are commensurate. So, it can be said that the term acquisition of language tends to explain how the mother tongue that a child gets.

To obtain language there are two processes that must be carried out by a child, namely, the process of competence and performance. In this competency process, it is stimulated by how a child masters an ongoing language without realizing it. To master this there are two processes, namely, (a) understanding, that is, how the child's ability to perceive sentences that he has heard, (b) can produce sentences, namely the level of children's ability to produce their own sentences. For the acquisition of a second language is interpreted when the child acquires another language after first he has mastered to the limit of the first language (Supritna, Rahmayanti, \& Endah, 2018).

A child who is not yet fluent in their language seeks to practice in order to speak, especially when speaking utterances in one or two words. Behavioristic model states that the acquisition of mother tongue is an exercise with repetition and association in children, this is one way for children to form their habits through conditioning. So, children who continue to practice language are the key to language acquisition.

This study aims to find out how the language acquisition of children aged 2.5 years through the utterances and utterances spoken in the speech they get from the environment, and know the mastery of the meaning of the utterances in speaking through phonological construction and syntax.

\section{METHOD}

This study is a qualitative study to find out how children's language acquisition is based on phonology, syntax at the age of 2.5 years. Data obtained through data collection techniques by recording speakers Princes Lawolo when he spoke by expressing words. 
When this research was conducted in May 2019 directly at the home of Princes Lawolo (as a research subject) jl. Batuang Taba, Lubuk Begalung District, Padang City. This research only focuses on acquiring phonology and syntax of Princes Lawolo who is only 2.5 years old. Princes Lawolo is the son of the father / mother parents of Defan Lawolo working as an entrepreneur, and the fourth child of five siblings.

\section{RESULTS AND DISCUSSION}

This part of the discussion will discuss how children's language acquisition is based on phonological and syntactical studies by Prince Lawolo, aged 2.5 years.

\section{Phonological and syntactic acquisition}

Phonological and syntactic acquisition

In linguistics phonology is an aspect contained in it that studies the phonemes and sounds spoken by children from the age of one year which will be seen in part from the acquisition of language (Herlina, 2016). Furthermore, the sound that is observed is the sound to distinguish the meanings of the term phoneme. Furthermore (Farisi, Syihabudin, \& Latthifah, 2017) stated that phonology is the branch of linguistics that studies sound.

This can be seen from the acquisition of phonology carried out by Princes Laowolo by saying some consonant sounds [c], [b], [a], and [m].

Data I

Princes (subject) : : "Coaulia" / let me see "Ina cu kue" / delicious cake

(while looking at the cellphone)

Her Mother : "It's delicious".

Data II

Her Mother : "whose child are you?

"(when his mother joked with him)

Princes (subject) : "Anak baw"/ father child

Data III

Her Mother : : "What do you do, Princes?"

Princes (subject) : "mai atu”/ playing rock

From the data above, in data I, the word "caulia" is a word that has no meaning, because the word being spoken is not in accordance with his statement to his mother. He said this word clearly when his mother played Mobile. When he says the sound [c] to the word "coaulia" it shows that Princes Lawolo can pronounce the sound [c]. Not just the word "coaulia", there are still words that he is able to say with the sound [c], which is "ina cu kue/ delicious cake.

Meanwhile, for alveolar-palatal [b], [a], [m], it appears when her mother jokes to her asking who she is whose child can be seen in data II and data III in Attas. For alveoplatal [b] that is word / father / he utters with the word / carry /, alveo-platal [a], with word / child / he calls the word / ana /, and word / stone / he utters the word / atu / While the alveo-platal $[\mathrm{m}]$ in the main word he pronounces the word / mai /.

Syntactic Acquisition

In general, researchers argue that language acquisition begins when a child begins to combine two or more words that have meaning (Hutabarat, 2018). For the acquisition of syntax the researcher does not start at the one word ranking stage (holofrase) because it has nothing to do with the development of syntax. according to Greendfield and Smith (in Chaer, 2009) that holophrase utterances are difficult to interpret or understand. to be able to interpret it the researcher must refer to the situation and context in which the holophrase is pronounced. But Clark and Garman (Chaer, op.cit.) Say that at the holofrase stage it will give some idea about the syntactic development in children.

The development of the syntax of the subject at this stage is getting better, especially at the one-word stage. As with the utterances of one syllable in the first stage, the syntactic form is still simple, but the semantics are complex. Like the words [kaka] "brother," [mae] "play," and [two] "two," each referring to different ethics, circumstances, and deeds. The word [kaka], for example, says the subject when he sees shoes, so perhaps the subject is saying that it is brother. Meanwhile the word [mae] was issued when the subject was playing with a laptop mouse.

Of the various words the subject has mastered, verbs and adjectives that have not yet appeared. While the dominant ones are nouns, which are around the names of people in the surrounding environment, for example: Data I

$\begin{array}{ll}\text { [yi] } & \text { "Debi" } \\ \text { [pade] } & \text { "Fadel" } \\ \text { [yiti] } & \text { "Fitri" } \\ \text { [tata] } & \text { "kakak" } \\ \text { [adi] } & \text { "Andi" }\end{array}$

Next, for the two syllable utterances at this stage several situations arise. For example, the word [ma two] appears when he is talking to his grandmother through a cellphone. In this situation the word [ma two] which he said naturally came out even though before he had been briefed by his mother. As seen in their dialogue the following:

\section{Data II}

Grandmother : (her grandmother's voice through her cellphone) "Hello" ...

Princes (subject) : "Ma, two ..." (What does he mean to buy? / (His grandmother asked).

Grandmother

: What Princes would you buy? / (Asks his grandmother)

Princes (subject) : "two"

Grandmother : : "What ... two ...?"

The word [ma] in the dialogue above is not meaningful / mama / but it is meaningful / oma /. From this dialogue it also appears that the subject has been able to respond to the questions asked to him. Although the answer is still not in the form of two-word even one-word utterances, for him and for children in general this word already has a complex meaning.

\section{CONCLUSIONS}

Based on the results of the above discussion, the researcher will conclude how the development and 
acquisition of the 2.5-year-old Princes Lawolo language based on phonological and syntactical studies.

\section{REFERENCES}

[1] Chaer, A. 2015. Psikolinguistik: Kajian Teoretik. Jakarta: Rineka Cipta.

[2] Dardjowidjojo, Soenjono dkk. 2003. Tata Bahasa Baku Bahasa Indonesia Jakarta: Balai Pustaka

[3] Farisi, A. M., syihabuddin, \& Lathifah, F. (2017). Analisis Kesalahan Fonologis dalam Keterampilan Membaca Teks Bahasa Arab. Pendidikan Bahasa Arab dan Kebahasaaraban, 4 (2), 174-184.

[4] Fatmawati, R. S. (2015). Pemerolehan Bahasa Pertama Anak menurut Tinjauan Psikolinguistik. Lentera , XVIII (1), 63-75.

[5] Herlina. (2016). Pemerolehan Fonologi pada Anak Usia Dua Bulan (Studi Kualitatif Pemerolehan Fonologi pada Aisyah). Pendidikan Usia Dini, 10 (2), 295-314

[6] Hutabarat, I. (2018). Pemerolehan Sintaksis Bahasa Indonesia Anak Usia Dua Tahun dan Tiga Tahun di Padang Bulan. Darma Agung, XXVI (1), 661-676.

[7] Pujaningsih. (2010). Perkembangan Bahasa dan Gangguan pada Anak Berkebutuhan Khusus. Pendidikan Khusus, 6, (1), 42-53

[8] Suddhono, K.,Sumarlam, \& Pandudinata, R. (2018). Pemeroleha Bahasa Siswa Tunangrahita Kelas Vi Sd. Retorika, 11 (1), 48-56.

[9] Ulfa, M. (2017). Pemerolehan Fonologi, Morfologi, dan Sintaksis Anak Usia 2,5-3 Tahun. Prosidinh Seminra Nasional Hasil Penelitian Pendidikan Pembelajaran, 3 (1), 1-13. 